\title{
Spatial relationship between earthquakes and volcanic vents in the central-northern Main Ethiopian Rift
}

\author{
Francesco Mazzarini $^{\mathrm{a}, *}$, Derek Keir ${ }^{\mathrm{b}}$, Ilaria Isola ${ }^{\mathrm{a}}$ \\ a Istituto Nazionale di Geofisica e Vulcanologia, Pisa, Italy \\ b National Oceanography Centre Southampton, University of Southampton, Southampton, UK
}

\section{A R T I C L E I N F O}

Article history:

Received 1 February 2013

Accepted 5 May 2013

Available online 28 May 2013

\section{Keywords:}

Volcanic vent

Earthquake

Spatial distribution

Self-similar clustering

Ethiopian Rift

Ethiopia

\begin{abstract}
A B S T R A C T
During the breakup of continents extension is commonly accommodated by connected networks of fluid filled fractures (dykes) and by faults. Despite the importance of these two extension mechanisms their spatial relationship in three dimensions is poorly understood primarily because it is difficult to quantify the subsurface distribution of faulting and intrusion. In order to address this problem, we conduct a quantitative analysis of the spatial distribution and clustering of earthquakes and volcanic vents in the Main Ethiopian Rift in East Africa in order to understand how extension by faulting and intrusion is distributed throughout the volcanic rift. We use fractal analysis of earthquake epicentres in order to infer the 2D characteristics of the subsurface fault network, and directly test our model results against the 3D distribution of earthquake hypocentres. Our results show that fractal analysis of these features is a reliable means to characterise the 3D properties of the fault network. In addition, the strong similarity between the properties of the fault network derived from earthquakes and properties of the magma-filled fracture network derived from fractal analysis of volcanic vents strongly suggests that these are genetically linked. We then explore their spatial link using computation of earthquake and vent density, which shows that the zone of seismicity is generally around $20-30-\mathrm{km}$-wide, while the zone of vents is narrower and centred within the zone of seismicity. This spatial relationship suggests that the faults, which form rift axial grabens, are induced above a narrower and central zone of diking. We also demonstrate significant along-rift variation in degree of magmatism and faulting with regions of increased degree of diking inferred from a higher cone density characterised by reduced degree of faulting.
\end{abstract}

(c) 2013 Elsevier B.V. All rights reserved.

\section{Introduction}

Seismic activity and active volcanism are normally spatially associated along plate boundaries and in some cases can be a hazard by disrupting lives and infrastructure. It is widely accepted that the transport of magma from lower crustal-upper mantle reservoir regions to its final level of emplacement mainly occurs through magma filled fracture networks (connected dykes and sills) (e.g. Lister and Kerr, 1991; Rubin, 1995; Petford et al., 2000). The style and depth of magma emplacement and/or eruption depends on the relative magnitude of magma buoyancy, the crust's fracture toughness, location of crustal mechanical discontinuities, and magma availability (e.g. Lister and Kerr, 1991; Rubin, 1995; Dahm, 2000; Gudmundsson, 2002). Ascending magma most commonly solidifies within the crust, resulting in sub-vertical blade-like dykes oriented perpendicular to the minimum compressive stress providing an efficient means to accommodate

\footnotetext{
* Corresponding author at: Istituto Nazionale di Geofisica e Vulcanologia, Via della Faggiola 32, 56126, Pisa, Italy. Tel.: + 39 0508311956; fax: + 390508311942.

E-mail address: mazzarini@pi.ingv.it (F. Mazzarini).
}

crustal extension (Rubin and Pollard, 1988; Bialas et al., 2010). In addition to magmatism, extension in tectonically active rifts occurs by faulting in the upper, brittle continental crust (e.g. McKenzie, 1978), and occurs when tectonic stress, or stresses induced by magma intrusion, loads brittle rocks to the point of failure generating an earthquake. The first order processes in the upper brittle crust that govern the generation of earthquakes and volcanoes are stress release and magma accumulation, respectively.

Along the rifts such as the East African Rift system (EARS), the distribution of earthquakes and volcanoes, formed from stress release and magma movement, can be used to estimate the complex spatial characteristics of the fracture network in the crust. Here we analyse spatial distributions of volcanic vents and seismicity utilising the catalogue of earthquakes from the 2001-2003 Ethiopia Afar Geoscientific Lithospheric Experiment (EAGLE), to define the spatial intensity of seismicity and vents along the Main Ethiopian Rift. We also use clustering analysis on both earthquakes and vents to model the characteristics of the subsurface fracture network beneath the rift valley and discuss the implications for where and how strain is accommodated during the rifting and breakup of other continents. 


\section{Study area}

The seismically and volcanically active EARS extends several thousands of kilometres and accommodates extension between the Nubian (African) and Somalian plates (Rosendahl, 1987; Braile et al., 1995; Chorowicz, 2005). At the northern end of the EARS, the volcanically active Main Ethiopian Rift (MER) records the transition from continental rifting to seafloor spreading in the Red Sea and Gulf of Aden (Hayward and Ebinger, 1996; Ebinger and Casey, 2001; Bonini et al., 2005; Corti, 2009; Agostini et al., 2011a). The rift valley in the MER separates the Ethiopian and Somalian plateaus, which are capped with Eocene-Oligocene flood basalts, isolated OligoceneMiocene shield volcanoes and Quaternary scoria cone fields (Kieffer et al., 2004; Rooney et al., 2011). The MER is a late Miocene NE-SW trending (in the north) to $\mathrm{N}-\mathrm{S}$ trending (in the south) fault bounded basin, filled by late Miocene to Recent volcanic rocks and continental sedimentary deposits (e.g. Corti, 2009 and references therein). Exposed volcanic products consist of basalts, rhyolites, ignimbrites and pyroclastic deposits. Monogenetic activity consists of spatter cones, scoria cones, maars and lava domes (Mazzarini et al., 1999; Abebe et al., 2005; Rooney et al., 2007; Corti, 2009; Rooney, 2010; Rooney et al., 2011).

Throughout the MER, strain distribution has been documented by geodetic, geophysical and geological observations (Boccaletti et al., 1998; Bilham et al., 1999; Ebinger and Casey, 2001; Wolfenden et al., 2004; Keir et al., 2006; Corti et al., 2013), with extension primarily localised to a NNE trending, 30-km-wide rift axis known as the Wonji Fault Belt (WFB) (Mohr, 1967) (Fig. 1). The WFB is segmented along its length into $~ 60-\mathrm{km}$-long, right stepping en-echelon volcanic systems (Ebinger and Casey, 2001), which consist of fault bounded lava units <2 Ma (Morton et al., 1979; Chernet et al., 1998; Abebe et al., 2005) and are characterised by a bimodal distribution of mafic and acidic magma types (e.g. Trua et al., 1999; Peccerillo et al., 2003).

The surface expression of segmentation may also manifest deeper within the crust. Crustal seismic tomography and gravity analysis show zones of high seismic velocity and high density at $\sim 7$ $10-\mathrm{km}$-depth below discrete segments of the WFB, interpreted as composed of predominantly cooled mafic intrusions (Keranen et al., 2004; Tiberi et al., 2005; Daly et al., 2008). These intrusions combined with faulting and fracturing of the crust, likely accommodated most of the extension (Keir et al., 2006, 2011a). High conductivities observed at both $\sim 2-\mathrm{km}$ and $\sim 15$-km-depth in a magnetotelluric survey across Boset volcano (Whaler and Hautot, 2006; Keir et al., 2009), combined with $<10-\mathrm{km}$-deep magma bodies beneath Corbetti, Aluto, Bora, Haledebi and Ayelu-Amoissa volcanoes modelled from InSAR data (Biggs et al., 2011; Keir et al., 2011b), suggests persistence of meltrich zones in both mid- and upper crust beneath many QuaternaryRecent volcanic centres.

Crustal structure of the MER has been imaged by recent wideangle controlled source seismic studies as well as using passive seismic techniques, both of which show crustal thickness varying from 30 to $35 \mathrm{~km}$ in the northern sector of the rift to about $35-40 \mathrm{~km}$ in the central sector (Mackenzie et al., 2005; Maguire et al., 2006; Stuart et al., 2006; Keranen and Klemperer, 2008; Keranen et al., 2009) (Fig. 2). Inversion of gravity data images a crustal section in the rift valley that is composed of 3-5 km of sedimentary infill overlying 20 km thick upper crust (Mahatsente et al., 1999; Cornwell et al., 2006; Mickus et al., 2007).

\section{Datasets}

The analysed datasets consist of seismicity and monogenetic vents in the northern and central Main Ethiopian Rift (Fig. 3). Coordinates of vent centres, earthquake epicentres and hypocentres have been acquired in UTM projection, datum WGS84, and have been stored in a GIS package for further handling and analysis.

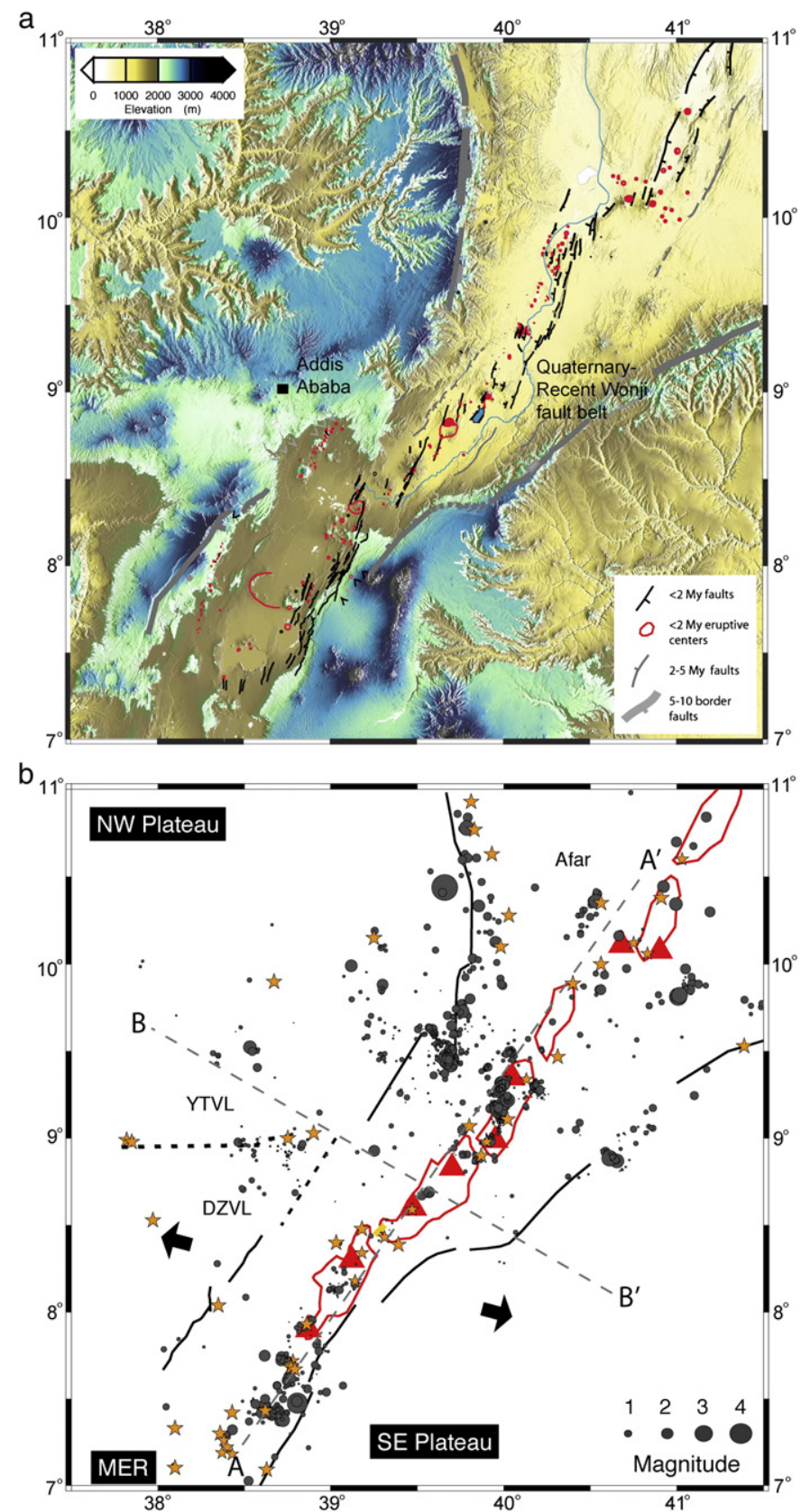

Fig. 1. a) Topography of the Main Ethiopian Rift, southern Afar and adjacent plateaus. Miocene age border faults are marked grey and Quaternary-Recent faults in the rift axis are marked black. Red closed lines are Quaternary-Recent volcanoes and cones. b) Tectonic sketch map of the same region shown in Fig. 1a with seismicity recorded during 2001-2003 (Keir et al., 2006) indicated by grey circles scaled according to magnitude. Quaternary-Recent volcanoes are red triangles. The black arrows indicate the direction of extension. Annotations are as follows: YTVL, Yerer-Tullul Wellel Volcano Tectonic Line (Abebe et al., 1998) and DZVL, Debre Zeyit Volcanic Line (Rooney et al., 2011). The profiles $A-A^{\prime}$ and $B-B^{\prime}$ shown in Fig. 2 are marked with dashed lines.

\subsection{Earthquakes}

Local earthquakes were derived from arrival times of earthquakes at four or more seismic stations composing the 2001-2003 EAGLE seismic network (Keir et al., 2006; Bastow et al., 2011), and using a best-fit 1-D seismic velocity model (Daly et al., 2008). From October 2001 to February 2003 within the MER, 1957 earthquakes were located and local magnitudes were determined, some of which are used for focal mechanism determination (Keir et al., 2006). Earthquake locations 

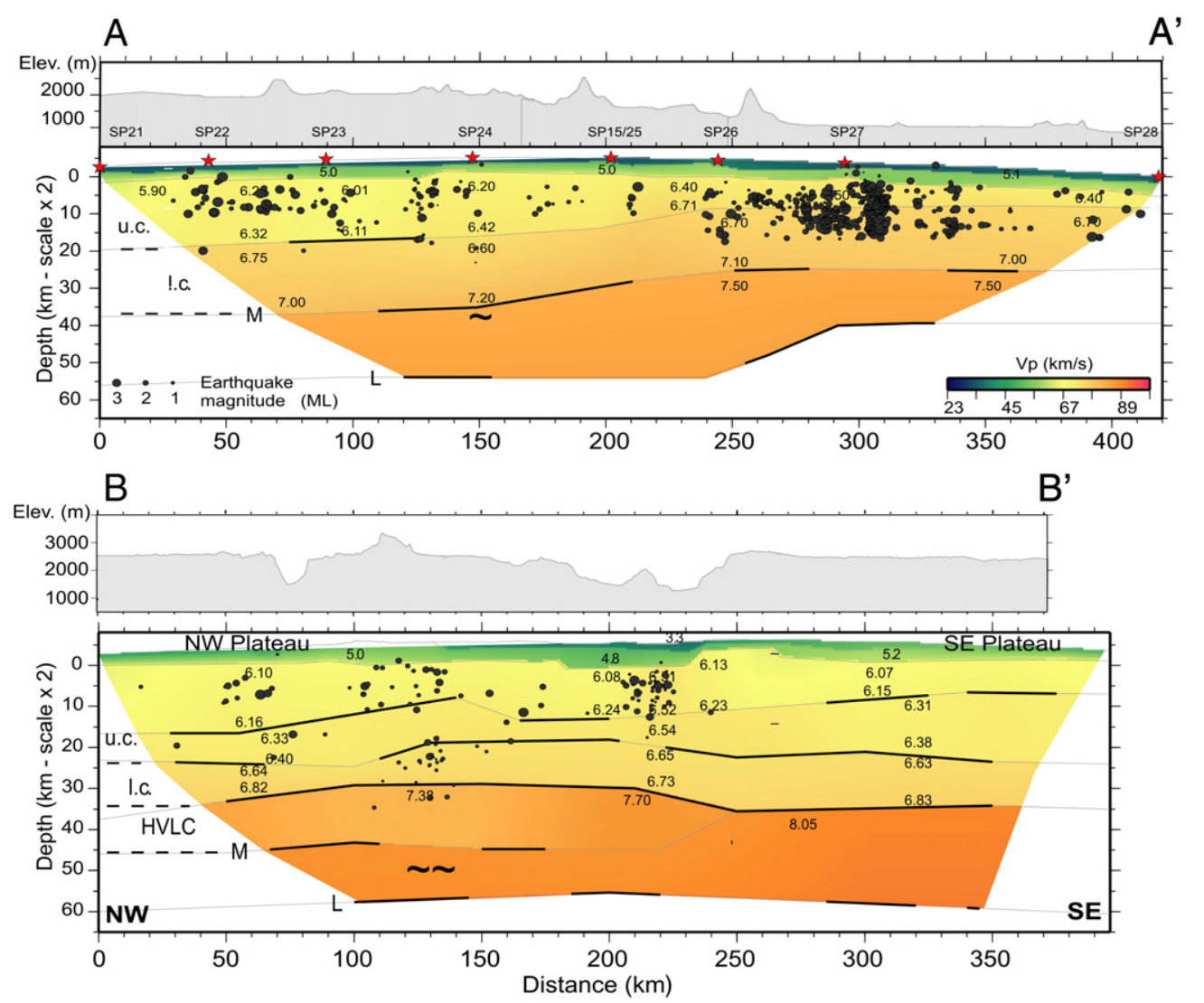

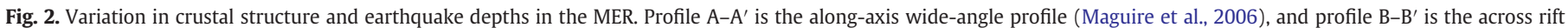
profile (Mackenzie et al., 2005).

Seismicity data is from Keir et al. (2006).

are constrained to within $\pm 600 \mathrm{~m}$ in horizontal directions and $\pm 2000 \mathrm{~m}$ in depth. The distribution of earthquakes shows that border faults of the MER are relatively seismically inactive, except for clusters of seismicity at the intersections between the MER and the older Red Sea and Gulf of Aden Rifts. The earthquake data have been acquired in a limited time interval, so the recorded seismic activity may not be completely representative of the long-term behaviour of the rift. Indeed, geological record of recent deformation has been documented along the rift's western border (Agostini et al., 2011b).

Along the axis of the MER, earthquakes are predominantly localised to depths of less than $\sim 12-15 \mathrm{~km}$ within the 30-km-wide WFB. Seismicity in these zones is characterised by low-magnitude $\left(M_{L} \sim 1-4\right)$ clusters broadly coincident with Quaternary-Recent faults, fissures and chains of eruptive centres. All but three focal mechanisms show normal dip-slip motion; the minimum compressive stress is $\mathrm{N} 103^{\circ} \mathrm{E}$, perpendicular to Quaternary-Recent faults and aligned volcanic cones (Keir et al., 2006).

\subsection{Vents}

In the studied areas, exposed volcanic products consist of lava flows, pyroclastic deposits and ignimbrites associated with central volcanoes, spatter and scoria cones, maars and lava domes. Holocene continental deposits and tephra are the youngest deposits (Woldegabriel et al., 1990; Abebe et al., 2005; Corti, 2009). The mapped vents correspond to different types of monogenetic volcanoes such as cinder or lava cones, domes, and maars. The ages of mapped vents range from about $2 \mathrm{Ma}$ to Recent. More evolved lavas (mainly rhyolites) are generally associated with domes, tuff rings and central volcanoes, whereas cones and maars are generally basaltic (Mazzarini et al., 1999; Corti et al., 2003; Lahitte et al., 2003a,b; Mazzarini, 2004; Mazzarini et al., 2004; Abebe et al., 2005; Mazzarini, 2007; Mazzarini et al., 2013). Vent locations have been acquired by surfing in Google Earth where panchromatic SPOT images (http://www.spotimage.com) with pixel resolution ranging from 2.5 to $20 \mathrm{~m}$ allow easy detection of vents (e.g. Mazzarini and Isola, 2010; Mazzarini et al., 2010). The collected dataset is a sample of the true vent population in the volcanic field. This sample clearly does not contain vents with diameter smaller than a few pixels (less than $10 \mathrm{~m}$ ), and vents that have been covered by younger volcanic products and continental deposits.

\section{Spatial distribution analysis}

The analysis of the spatial distribution of earthquakes and vents has been performed in terms of their average separation, density and intensity and by analysing vent and earthquake self-similar clustering.

The average separation between samples (nearest neighbour distance) has been analysed in terms of the Coefficient of Variation (CV), defined as the ratio between the standard deviation and the mean of the sampled population (Gillespie et al., 1999). A value of CV $>1$ results from the clustering of samples, when $\mathrm{CV}=1$ a random or Poisson distribution of samples is evident, and $\mathrm{CV}<1$ is the result of anti-clustering (a homogeneous distribution) of samples. It is important to note that the CV parameter investigates how close samples are to one another, and does not probe any occurrence of patterns in the sample distribution.

For earthquakes and vents, we have analysed the density using a two dimensional symmetric Gaussian kernel density estimate (Connor and Hill, 1995; Kiyosugi et al., 2012):

$\lambda(v)=\frac{1}{2 \pi h^{2}} \sum_{i=1}^{N} e^{\frac{-d_{i}^{2}}{2 h^{2}}}$ 


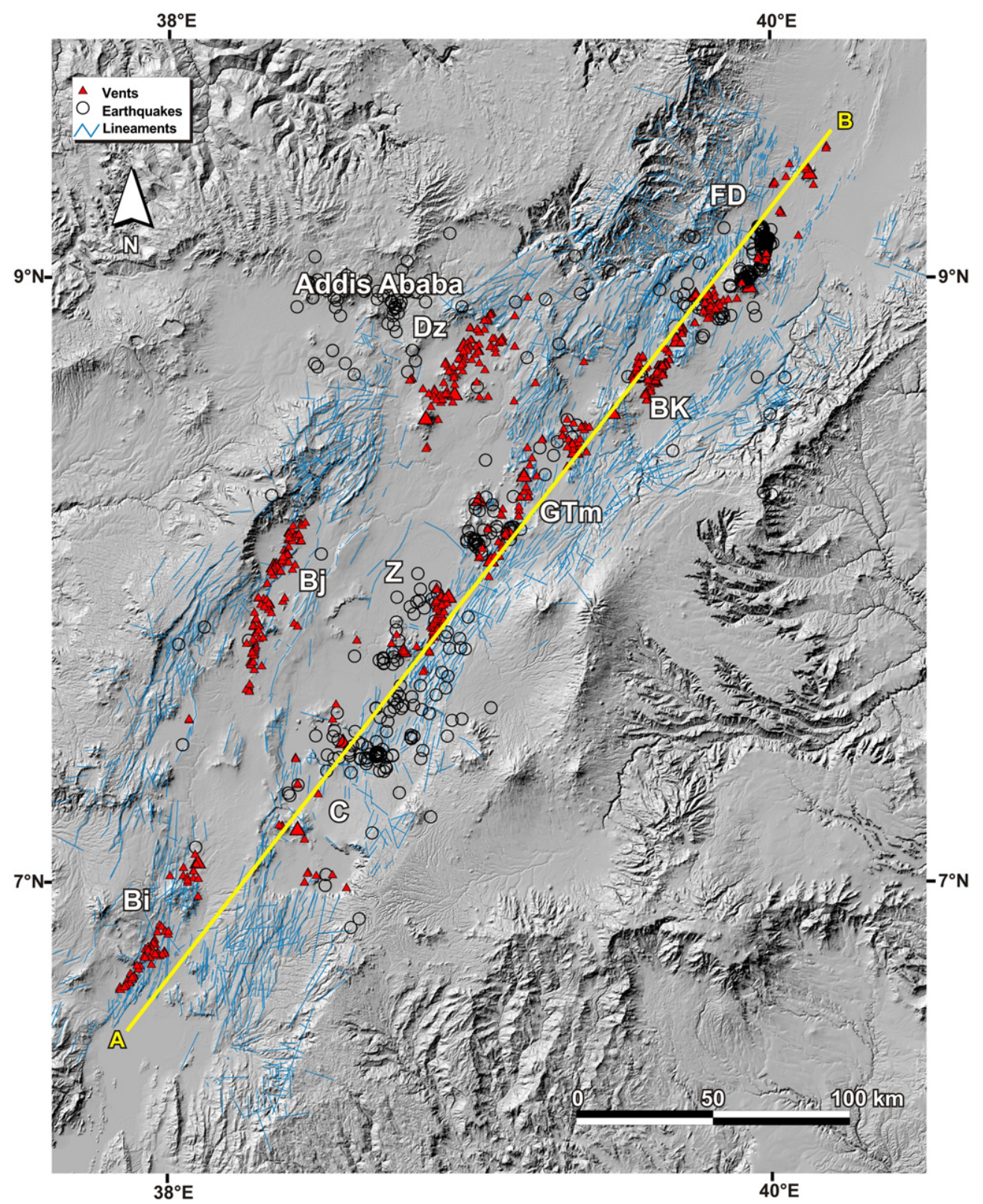

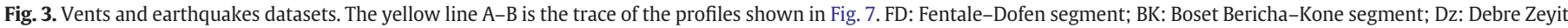
segment; GTm: Gedemsa-Tullu Moje segment; Z: Zway segment; Bj: Butajira segment; C: Corbetti Caldera segment; Bi: Bilale segment.

Main faults are derived from Mazzarini and Isola (2010).

where $\mathrm{d}_{\mathrm{i}}$ is the distance between sample $v$ and the other $N-1$ samples, and $h$ is the smoothing bandwidth. In this way, the frequency distribution of "neighbour" samples is inferred. Distance values between neighbour samples larger than $h$ have a small weight in the computation of the density estimate. We used a variable $h$ value, consisting of the half value of the distance between each sample and its nearest sixth neighbour (Favalli et al., 2012). Finally, vent separation as well as earthquake depth has been projected onto an $400 \mathrm{~km}$ long and NE-SW trending crustal profile running along the rift valley in order to compare their relative distributions (Fig. 3).

\subsection{Self-similar clustering of vents and earthquakes}

A direct genetic and spatial link between fracture and vent occurrence has been previously observed in a number of settings such as continental rift, central volcanoes and magmatic arcs (e.g., Tibaldi,
1995; Connor and Conway, 2000; Mazzarini, 2004; Mazzarini and Isola, 2010; Kiyosugi et al., 2012), providing strong evidence that scale invariance in vent distribution reflects the fractal properties of the connected part of a fracture network (i.e., the backbone). The correlation between vent distribution and the properties of a fracture network is such that the spatial distribution of vents may be studied in terms of self-similar (fractal) clustering (Mazzarini, 2004; Mazzarini and Isola, 2010), as in the case of fracture networks (Bour and Davy, 1999; Bonnet et al., 2001). Findings based on this approach suggest that, for basaltic volcanic fields, (i) the distribution of monogenetic vents is linked to the mechanical layering of the crust, (ii) that vents tend to cluster according to a power-law distribution, and (iii) the range of lengths over which the power-law distribution is defined is characterised by an upper cut-off that approximates the thickness of the fractured medium (crust) between the source (magma reservoirs) and the sink (surface). This correlation has been 
studied in volcanic fields located in a range of geodynamic settings: continental rifts such as the East African Rift System (Mazzarini, 2004, 2007; Mazzarini and Isola, 2010), extensional continental back-arc settings such as in southernmost Patagonia (Mazzarini and D'Orazio, 2003), transtensional settings such as volcanic fields along the Trans-Mexican Volcanic Belt (Mazzarini et al., 2010), and within compressional continental settings at the rear of the Andes chain in northernmost Patagonia (Mazzarini et al., 2008). The scaling of upper cut-off value with the distance between surface and source for fluids has also been observed for mud volcanoes growing during crustal shortening in Azerbaijan (Bonini and Mazzarini, 2010).

In this study we apply this methodology to both vents and earthquakes. Uniquely, the earthquake dataset, which includes both epicentre and hypocentre information provides the opportunity to directly test whether the 3D properties of the fracture network can be inferred from 2D information.

We analysed the fractal distribution of earthquakes and vents using a two-point correlation function method. For a population of $N$ points (vent centres, epicentre, hypocentre) the correlation integral $C(l)$ is defined as the correlation sum that accounts for all the points at a distance of less than a given length $l$ (Hentschel and Procaccia, 1983; Bonnet et al., 2001). In this approach, the term $C(l)$ is computed
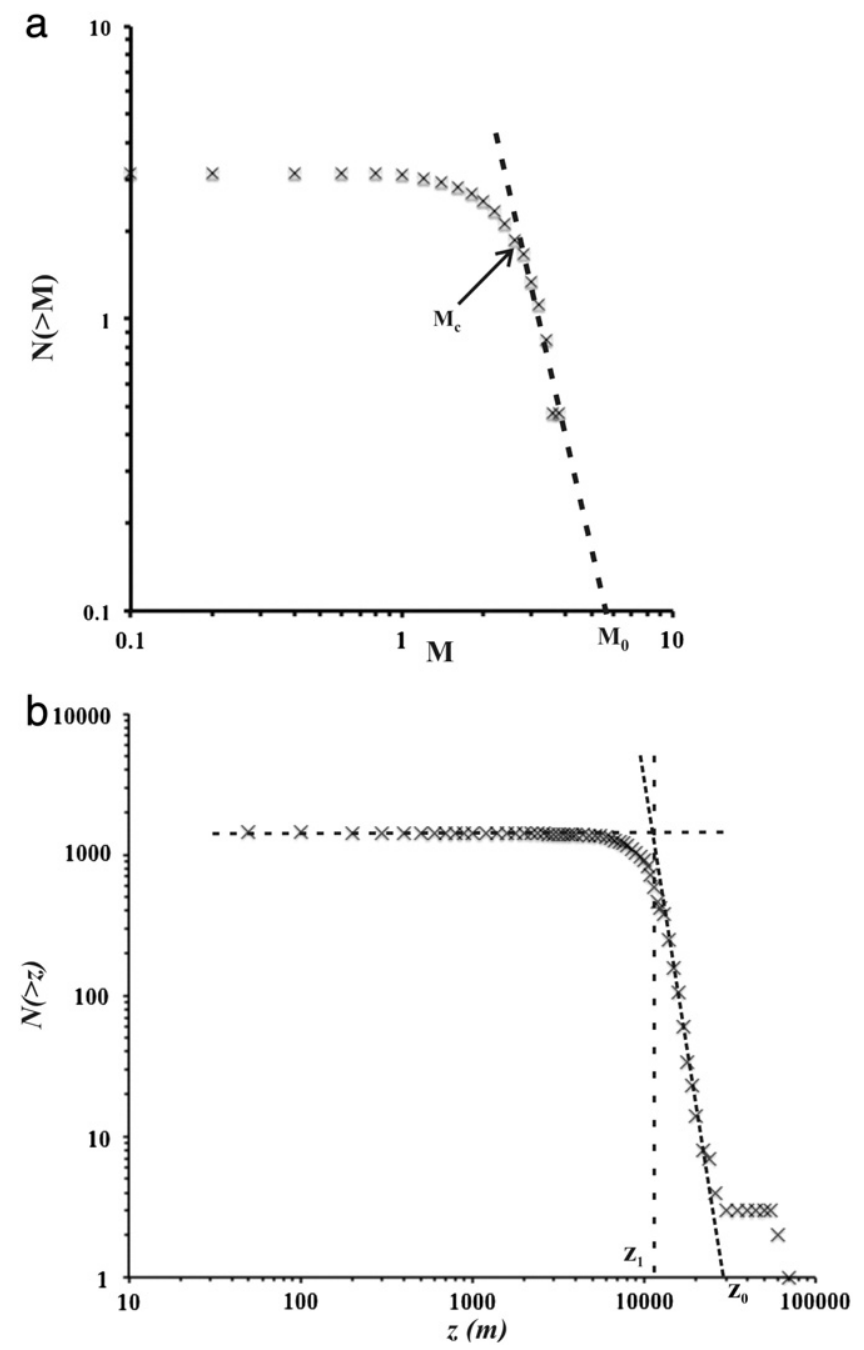

Fig. 4. a) Earthquake magnitude distribution according to the Gutenberg-Richter relation. $\mathrm{M}_{\mathrm{c}}$ : completeness magnitude; $\mathrm{M}_{0}$ : maximum expected magnitude. b) Earthquakes' depth distribution. $Z_{0}$ : maximum expected depth derived by the distribution imposing $N(>\mathrm{Z})=1 ; \mathrm{Z}_{1}$ : fractal distribution lower bound. as $C(l)=2 N(l) / N(N-1)$ where, $N(l)$ is the number of pairs of points whose distance is less than $l$. Fractal distribution of $C(l)$ is defined by:

$C(l)=c l^{D}$

where $c$ is a normalisation constant and $D$ is the fractal exponent.

If scaling holds, Eq. (2) is valid, and the slope of the curve in a $\log (C(l))$ vs. $\log (l)$ diagram yields the $D$ value that is defined by the fractal exponent $(D)$, the higher the $D$ value the less clustered the system. The computed $D$ value is valid for a defined range of distances (l). The distance interval over which the scaling of $C(l)$ with $l$ is valid is the size range. Within the size range the linear fit of the curve is well defined and the angular coefficient of the straight line is the fractal exponent. The local slope $(\Delta \log (C(l) / \Delta \log (l))$ is a point by point measure of the slope of the tangent to the curve; where the linear fit holds the curve is a straight line and the local slope (the angular coefficient of the regression line) is constant. For each analysis, the size range of samples is in turn defined by a plateau in the local slope vs. $\log (l)$ diagram: the wider the range the better the computation of the power-law distribution (Walsh and Watterson, 1993). The size range is bounded between two values; the lower ( $L C O)$ and the upper (Uco) cut-offs, respectively. The choice of the zones where the plateau in the graph is well defined and the determination of the cut-offs are following the methods of Mazzarini (2004) - the wider length range for which the correlation between $\log (l)$ and local slope is greatest was selected. As rule of thumb, a size
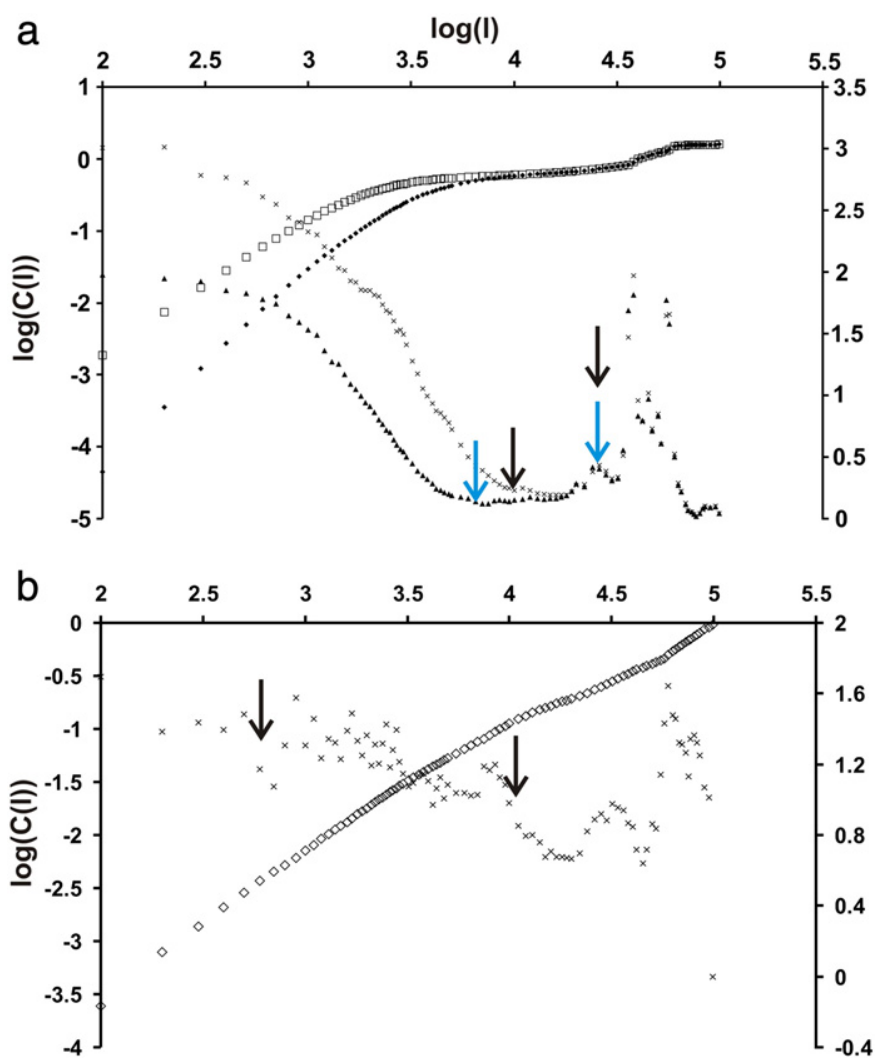

Fig. 5. a) Log-log plots of self-similar scaling for earthquakes epicentres and relative local slope (open squares and black triangles, respectively), and for earthquakes hypocentres and relative local slope (black diamonds and crosses respectively). Cyan arrows represent the lower and upper cut offs for epicentres and black arrows represent the lower and upper cut offs for hypocentres. b) Log-log plots for self-similar scaling for vents and relative local slope (open diamonds and black crosses respectively). Black arrows represent the lower and upper cut offs for vents. 
Table 1

Self-similar clustering parameters for vents and earthquakes.

\begin{tabular}{|c|c|c|c|c|c|c|}
\hline Dataset & $N$ & $c$ & $D$ & $\mathrm{R}^{2}$ & Lco $(\mathrm{km})$ & Uco $(\mathrm{km})$ \\
\hline Vents & 702 & $2 \times \times 10^{-6}$ & $1.21 \pm 0.01$ & 0.997 & $0.6 \pm 0.1$ & $10.6 \pm 1.1$ \\
\hline Earthquake epicentre (2D) & 1439 & 0.1487 & $0.15 \pm 0.02$ & 0.999 & $5.5 \pm 1.1$ & $18.0 \pm 1.5$ \\
\hline Earthquake hypocentre (3D) & 1439 & 0.0738 & $0.22 \pm 0.02$ & 0.997 & $8.5 \pm 1.1$ & $18.0 \pm 1.5$ \\
\hline
\end{tabular}

$N$, data number; $c$, normalisation constant; $D$, fractal exponent; $\mathrm{R}^{2}$, correlation coefficient; $L c o$, lower cut off; Uco, upper cut off.

range of at least one order of magnitude and at least 150 samples is required to extract robust parameter estimates (Bonnet et al., 2001; André-Mayer and Sausse, 2007; Clauset et al., 2009). Mazzarini and Isola (2010) show that removing a random sample of $20 \%$ of the vents from large (i.e. $>200$ vents) datasets does not affect the estimation of fractal dimension (less than $0.01 \%$ of variation) and the error introduced into the estimation of the cut-offs is less than $1 \%-2 \%$.

We also tested the effect of uncertainties in vent locations by adding random errors (in the $0-100 \mathrm{~m}, 0-300 \mathrm{~m}$ and $0-500 \mathrm{~m}$ ranges) to the sampled vents. In this test, the added errors are as high as five to twenty five times that of the coarsest image resolution we used to locate vents. The $0-100 \mathrm{~m}$ errors randomly added to the vent locations generate fractal exponent and cut off value identical to those computed for the original dataset. In the case of $0-500 \mathrm{~m}$ random errors, the resulting fractal exponent is 3\% higher than that computed for the original dataset, and the cut offs are very similar to those computed for the original dataset.

The vent self-similar clustering method investigates how points distribute by analysing their mutual neighbour relationships and it is very sensitive to the structural control.

\section{Results}

\subsection{Earthquakes}

From the original data, we selected 1439 earthquakes located within the study area with hypocentre depth $>100 \mathrm{~m}$ (Fig. 3). Earthquake magnitude varies between -2.3 and 3.9, averaging 1.6 with a standard deviation of 0.6 . The magnitude size distribution (Fig. 4a) has a b value of 1.16, a magnitude of completeness $\left(\mathrm{M}_{\mathrm{c}}\right)$ of 1.6 , and maximum expected magnitude of $4.9\left(\mathrm{M}_{0}\right)$.

Earthquake depth varies from 0.1 to $35.9 \mathrm{~km}$ with an average of $11.0 \mathrm{~km}$ and standard deviation of $4.4 \mathrm{~km}$. Earthquakes with depth greater than $20 \mathrm{~km}$ comprise less than $1 \%$ of the data, and those with depth shallower than $15 \mathrm{~km}$ comprise $89.2 \%$ of the data. The depth distribution of earthquakes suggests that the seismogenetic crust is about 15-16 km thick, with the majority of rift axial earthquakes beneath the Fantale-Dofen segment at 9-15 km depth. Some deeper earthquakes greater than $20 \mathrm{~km}$ depth are present but mostly restricted to beneath Quaternary-Recent volcanic fields on the western border of the northern MER. The log-log plot of cumulative distribution of earthquake depth $(\mathrm{z})$ shows a linear trend in the $11-22 \mathrm{~km}$ range $\left(\log (N(>\mathrm{z}))=-7.77 \log \mathrm{z}+34.6, \mathrm{R}^{2}=0.992\right)$. The maximum expected depth derived by the distribution imposing $N(>\mathrm{z})=1$ is $\sim 30 \mathrm{~km}\left(\mathrm{Z}_{0}\right)$, whereas the fractal distribution lower bound $\left(Z_{1}\right)$ is $\sim 11 \mathrm{~km}$ (Fig. 4b). Hypocentre accuracy for earthquakes is generally $0.6 \mathrm{~km}$ in the horizontal direction and $2 \mathrm{~km}$ in depth (Keir et al., 2006). Epicentre separation is $0.8 \mathrm{~km}$ on average with standard deviation of $2.1(\mathrm{CV}=2.6)$; hypocenter separation is $1.8 \mathrm{~km}$ on average with standard deviation $2.9(\mathrm{CV}=1.6)$.

Earthquake self-similar clustering has been computed by applying Eq. (2) to epicentre (2D) and hypocentre (3D) datasets. The epicentre dataset shows self-similar clustering with fractal exponent $D=0.15$ in the $5.5-18 \mathrm{~km}$ size range, and the hypocentres dataset
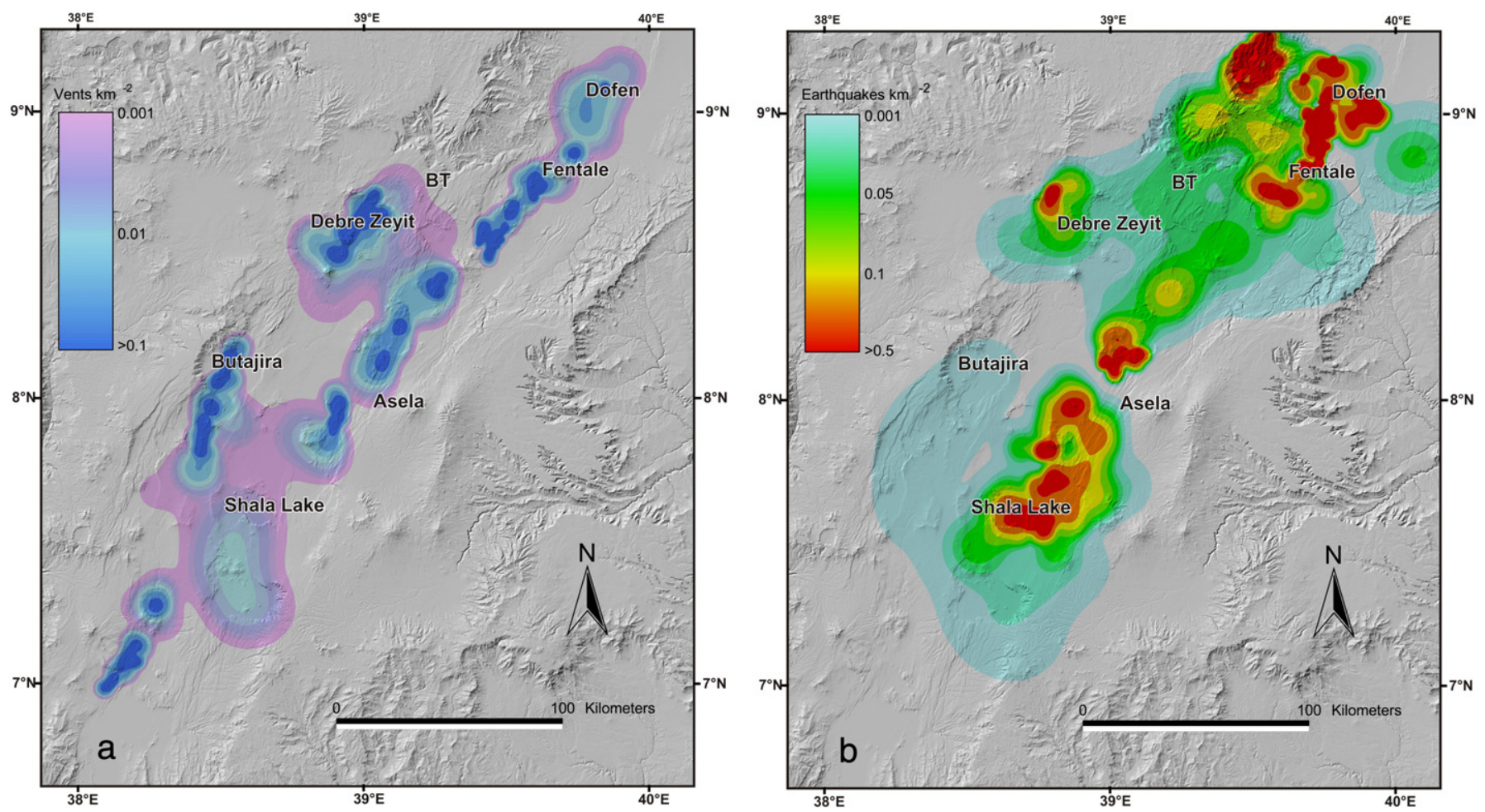

Fig. 6. Density maps for vent (a) and earthquake epicentres (b). BT: Boru Toru. 
has fractal exponent $D=0.22$ in the $8.5-18 \mathrm{~km}$ size range (Fig. 5a; Table 1).

Earthquake density, computed using Eq. (1), varies from $10^{-3}$ to $>5 \times 10^{-1}$ earthquakes $\mathrm{km}^{-2}$. Large earthquake clusters are north of Boru Toru (BT in Fig. 6), north-west of Debre Zeyt and along the

a $\circ M$

O Z-eqk

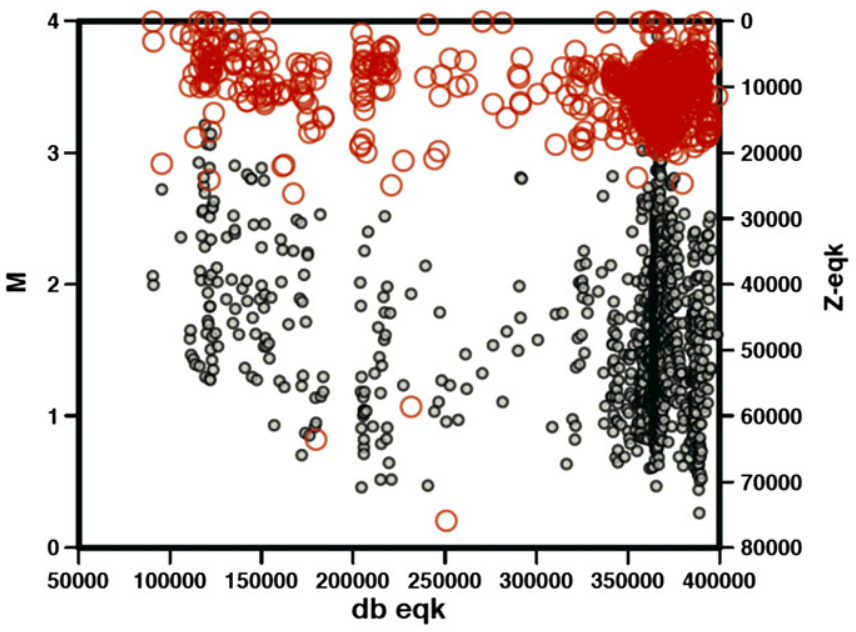

b

b $\quad \begin{array}{ccccc}\text { bdb east } & \text { db eqk } & \bigcirc & \text { db eqk }\end{array}$

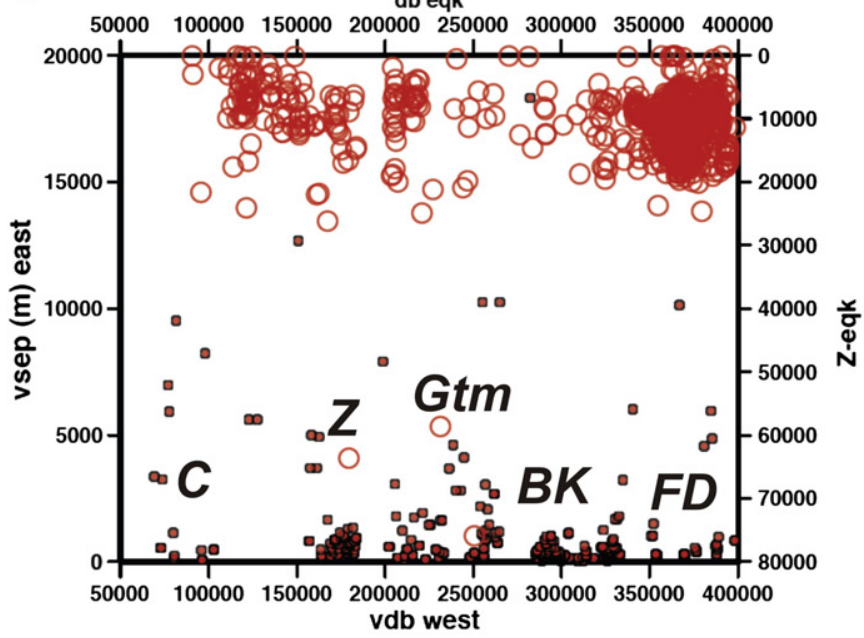

C

- vdb west

db eqk

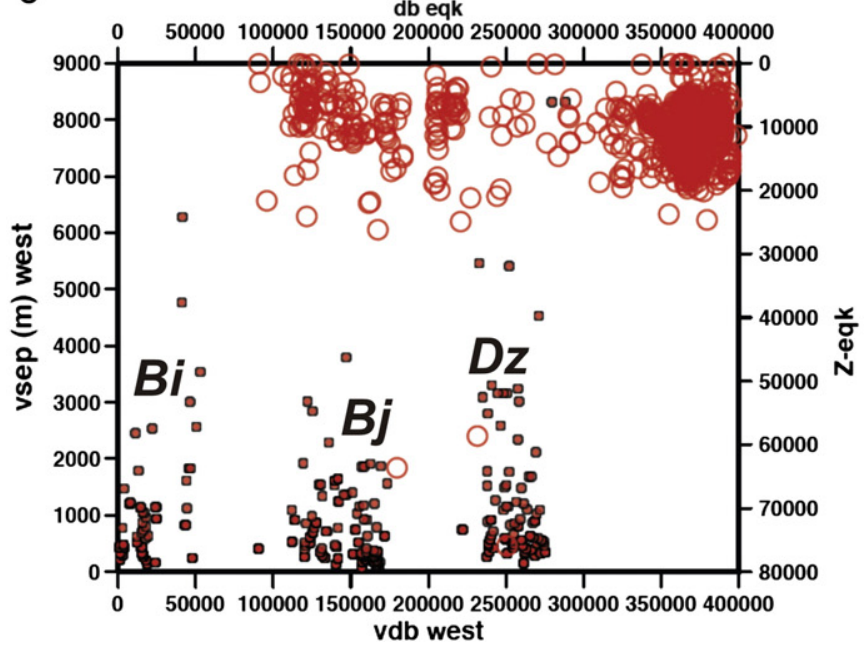

WFB at the latitude of Asella where the WFB is adjacent to the rift margin (Fig. 6a).

\subsection{Vents}

In the studied area, 702 vents have been mapped, their separation varies $0.03-18.7 \mathrm{~km}$, with an average of $1.0 \mathrm{~km}$ and a standard deviation of $1.8 \mathrm{~km}(\mathrm{CV}=1.8)$. Vents show self-similar clustering with fractal exponent $D=1.21$ in the $0.6-10.6 \mathrm{~km}$ size range (Fig. $5 \mathrm{~b}$; Table 1).

Vents are distributed along an axial belt (WFB) and a belt close to the western border of the rift valley; they are clustered in segments (Fig. 6b). Vent density, computed using Eq. (1), varies from $10^{-3}$ to $10^{-1}$ vent $\mathrm{km}^{-2}$. The axial belt starts in the northern MER at Dofen volcano and extends south to $7.5^{\circ} \mathrm{N}$ at Lake Shalla. The western belt is in the central MER and starts at the latitude of Debre Zeyit and continues along the western border south of Lake Shalla (Fig. 6b).

\section{Discussion}

\subsection{Self-similar clustering}

Earthquake epicentres and hypocentres, as well as volcanic vents have clustered distributions ( $C V>1)$. Vent self-similar clustering along the central MER has an upper cut off of $\sim 11 \mathrm{~km}$ (Table 1), in accordance with estimates by Mazzarini and Isola (2010) and Mazzarini et al. (2013). Controlled source seismic imaging shows that along the volcanic belts below $\sim-10 \mathrm{~km}$ depth the crust is heavily modified by dense gabbroic intrusions (Keranen et al., 2004; Rooney et al., 2005; Maguire et al., 2006; Keranen et al., 2009). Above these, the uppermost crust is intruded by basaltic sheeted dykes to a lesser extent, with these intrusions feeding vent eruptions (Ebinger and Casey, 2001). Self-similar scaling of vents has been observed in several volcanic fields and the upper cut offs of respective fractal distributions have been associated with the depth of the magmatic reservoirs (Mazzarini et al., 2013 and references therein). Our analysis showing a vent self similar clustering upper cut off of $\sim 11 \mathrm{~km}$ suggest that the gabbro intrusions likely represent solidified magma reservoirs that fed the shallower mafic intrusions.

Self-similar clustering has also been observed for earthquake epicentres (2D) and hypocentres (3D). The lower cut off of the 3D dataset is not as clearly defined as that of the 2D dataset due to relatively low resolution of hypocentral depths, whereas the upper cut offs of both datasets are clearly identified sharing the same value of $\sim 18 \mathrm{~km}$ (Table 1). The upper cut-off of $\sim 18 \mathrm{~km}$ is similar to the thickness of the seismogenic crust in the rift interpreted directly from the seismological data (Keir et al., 2006).

The upper cut off values for earthquakes and vents could potentially be used for interpreting the earthquake depth distribution beneath volcanic fields. The brittle seismogenic crust extends to up to $18 \mathrm{~km}$ depth (earthquake upper cut off) whereas at shallower crustal levels of $10-11 \mathrm{~km}$ (11 km vent upper cut off) both tectonic (earthquakes) and magmatic (diking) deformation may occur. Moreover, self-similar clustering for both vent and earthquake distributions (Fig. 5, Table 1), strongly suggests that both the earthquake

Fig. 7. Transects of earthquakes and vent distributions along the rift strike, vents are grouped in main volcanic segments identified by the initials of main volcanic edifices or localities as in Fig. 3. a) Distribution of earthquake depths (open red circles) and magnitude (grey circles). b) Distribution of earthquake depths (open red circles) and vents along the rift axis (red filled small circles). FD: Fantale Dofen segment, BK: Boset-Bericha Kone segment, GTm: Gedemsa Tullu Moje segment, Z: Ziway cluster, C: Corbetti caldera segment. c) Distribution of earthquake depths (open red circles) and vents along the western border of the rift (red filled small circles). Dz: Debre Zeyit segment, Bj: Butajira segment, Bi: Bilale segment. 
and magmatic deformation occur within the same fracture network. Fractal exponents of the 2D and 3D datasets are less than 1, suggesting that both distributions are characterised by a high degree of earthquake clustering and that clustering varies very little with distance between earthquake pairs.

A major outstanding question is whether 2D fractal analysis can be used to characterise a network that operates in 3D. It is well known that joints in thinly layered sedimentary rock typically span the mechanical thickness of the layer and the general linear relationship between spacing and layer thickness has been observed (Narr and Suppe, 1991; Gross, 1993; Renshaw, 1997). Theoretically, as observed for trace length distributions of fractures, power law in 2D analysis remain power law also in 3D analysis accordingly to the following relationship between exponents: $\mathrm{a}_{2 \mathrm{D}}=\mathrm{a}_{3 \mathrm{D}}-1$ (e.g., Darcel et al., 2003a,b). Moreover, according to Bour et al. (2002) spatial correlation analysis of fractures is valid whatever the point used to define fracture location (barycentre, fracture tips, or any point taken at random in the fracture). Analysed vents are tied to feeders (fractures with magma) and can be considered points along the fracture traces, thus sampling the intersection of the connected network with the surface (e.g., Kiyosugi et al., 2012). The uncertainties in event location likely generates important truncation effects (e.g. Bonnet et al., 2001) leading to overestimation of the earthquake clustering, thus producing smaller values of fractal exponents than if the earthquakes could be located without error.

Nonetheless, the strong similarity between upper cut offs derived by fractal analysis of earthquake epicentres (2D) and hypocentres (3D) provides, for the first time, strong quantitative experimental support for the inference of the spatial distribution of 3D datasets by analysing their map distribution (Table 1 ).

\subsection{Spatial distribution}

Along the axis of the MER, the spatial distribution of earthquakes broadly correlates with that of vents. The greater width of the active zone of faulting, shown from the maximum in seismicity intensity, than the width of the zone of vents is consistent with formation of 60-degree dipping normal faults that dip inwards and towards a

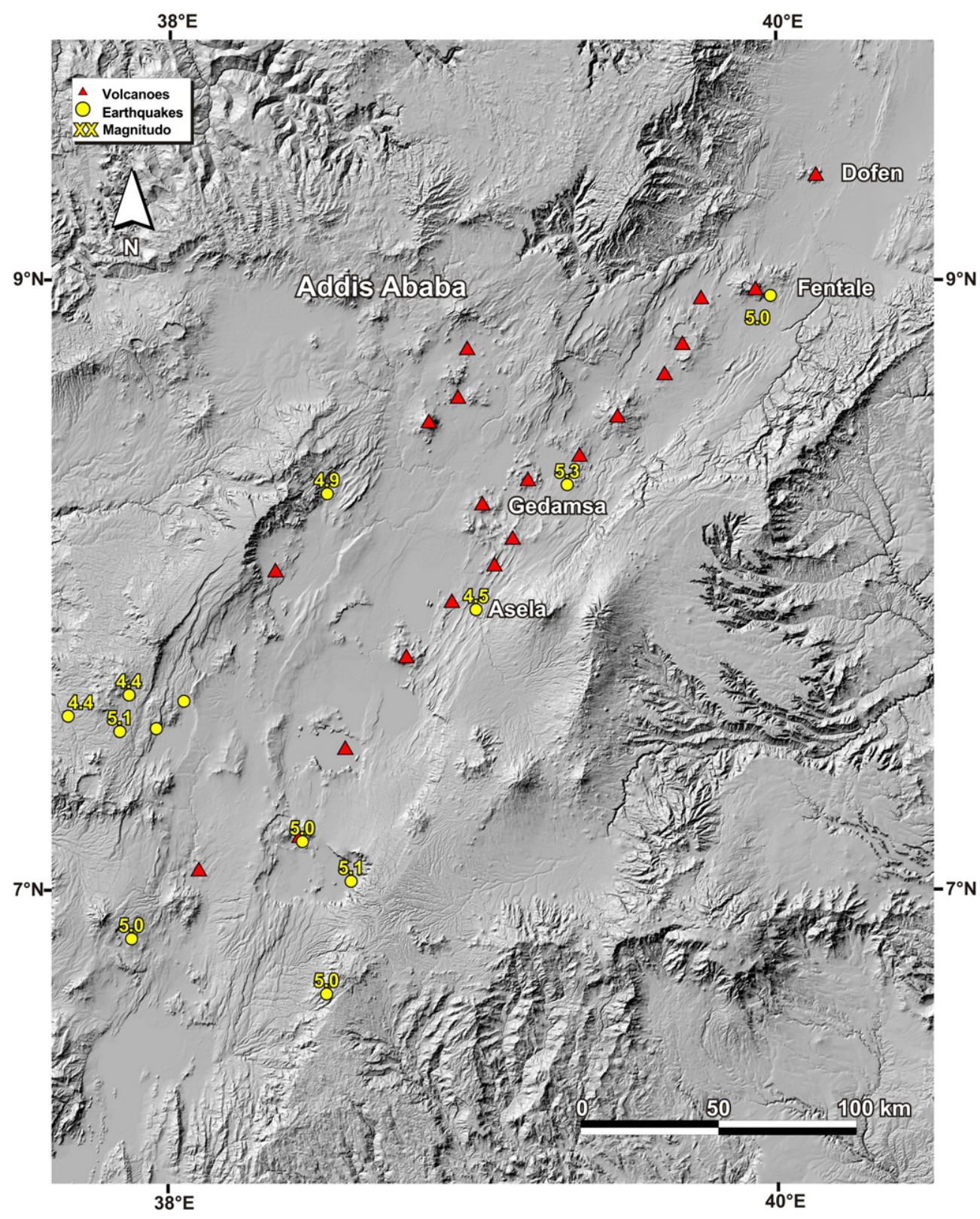

Fig. 8. Map and transect of catalogue earthquakes and volcanoes from the USGS. 
central zone of diking (Rubin and Pollard, 1988; Behn et al., 2006). Along the western margin of the rift valley the correlation between vents and earthquakes is relatively poor. Near Debre Zeyit for example, earthquakes concentrate more westward than vents. Other vent fields such as the Butajira field are aseismic.

Earthquake depth and vent separation have been projected along a crustal profile nearly parallel to the MER (Figs. 3 and 7). Earthquake depth shallows from northeast (Dofen volcano) to southwest (Lake Shalla). At the latitude of Kone and Boset volcanoes, earthquake depth dramatically shallows and most of the events are shallower than $10 \mathrm{~km}$. North-east of Kone, earthquakes reach 18-20 km depth (Fig. 7a). Maximum earthquake magnitude occurs at the latitude of the northern (Dofen-Fantale) and southern portion of the profile, whereas low magnitude earthquakes are observed along the profile between Kone and Boset in correspondence of maxima in vent density (Figs. 3 and 7). This is apparent in Fig. 7b and c where axial and western volcanic belts are projected on the NE-SW transect (Fig. 3). Vents in the western border of the rift start at Debre Zeyit (Dz in Figs. 3 and 7b) corresponding to the sector along the profile with the lowest earthquake density. The Fantale-Dofen volcanic segments in the axial belt (FD in Figs. 3 and 7c) is located in the portion of the profile where earthquakes have their highest frequency; in this portion of the rift the Boset-Kone segment (BK in Figs. 3 and 7c) is located where earthquake frequency decreases and earthquakes depth shallows. Most of the vents in the axis of the rift (Boset-Kone and Gedemsa Tullu Moje segments, BK and GTm in Figs. 3 and 7c) are localised in the zone where earthquake occurrence is low, and indicates that portions of the rift with greater surface manifestation of magmatism undergo a lower proportion of extension by faulting.

The magnitude distribution follows the Gutenberg-Richter relation with exponent $b \geq 1$ (1.16), completeness magnitude $\left(M_{c}\right)$ 1.6, and maximum expected magnitude $4.9\left(\mathrm{M}_{0}\right)$. Our maximum expected magnitude of 4.9 compares well with the largest magnitude $(M=5)$ of earthquakes recorded since 1973 on the NEIC catalogue. These relatively large earthquakes occurred in the rift valley and on the rift western border (Fig. 8). The NEIC catalogue also shows that large magnitude earthquakes $(M \geq 4)$ are more frequent in the southern portion of the central MER (Fig. 8). The southward increase in seismic moment release and shift in seismicity from axial volcanic segments to border faults is concomitant with a significant decrease in overall vent density. These coupled observations suggest that extension in the southern MER is accommodated mainly by faulting on border faults, an interpretation supported by GPS measurements showing that extension in southern MER is localised mainly to the western border fault (Kogan et al., 2012). The along-rift variation in number and distribution of large magnitude earthquakes coupled with the distribution of major volcanic centres suggests that border faulting accommodates a significant proportion of strain in the southern MER. In the central MER, however, axial magma intrusion and intrusion controlled axial faulting have localised deformation to a narrower zone. Similar along rift variations in degree of magmatism may persist until the onset of seafloor spreading resulting in significant variations in degree of intrusion, crustal thickness, and width of the continent-ocean transition along rifted continental margins (e.g. Shillington et al., 2009).

\section{Conclusions}

Using analysis of fractal distributions of epicentre and hypocentre datasets we experimentally show that 2D fractal analysis can characterise a network that operates in 3D. The distribution of earthquakes hypocentre provides an independent proof on the reliability of using 2D (map) data to infer 3D (crustal) features.

We explore the spatial contiguity between earthquakes and vents. Most of seismicity and volcanic vents are beneath the axial volcanic segments confirming that most of the crustal strain within the rift is localised to the 20-30-km-wide rift axis. Within this belt, the zone of seismicity is generally around $30-\mathrm{km}$-wide, while the zone of vents is narrow and centred within the zone of seismicity. This spatial relationship suggests that the faulting forming rift axial grabens is induced above a narrower and central zone of diking.

Seismicity increases in magnitude in the southern portion of the rift, where volcanism is less expressed. This suggests that in the central MER most of crustal strain is accommodated by magma intrusion. In regions of reduced dyke intrusion, an increased proportion of strain is accommodated by slip on main border faults. Similar along rift variations in degree of magmatism may persist until the onset of seafloor spreading resulting in significant variations in degree of intrusion, crustal thickness, and width of the continent-ocean transition along rifted continental margins.

\section{References}

Abebe, T., Mazzarini, F., Innocenti, F., Manetti, P., 1998. The Yerer-Tullu Wellel volcanotectonic lineament: a transtensional structure in central Ethiopia and the associated magmatic activity. Journal of African Earth Sciences 26, 135-150. http://dx.doi.org/ 10.1016/S0899-5362(97)00141-3.

Abebe, T., Manetti, P., Bonini, M., Corti, G., Innocenti, F., Mazzarini, F., Pècksay, Z., 2005. Geological map (scale 1:200.000) of the northern Main Ethiopian Rift and its implications for the volcano-tectonic evolution of the rift, Map and Chart MCH094, 20 pp. Geol. Soc. Am., Boulder, Colo., http://dx.doi.org/10.1130/2005MCH094TXT.

Agostini, A., Bonini, M., Corti, G., Sani, F., Mazzarini, F., 2011a. Fault architecture in the Main Ethiopian Rift and comparison with experimental models: implications for rift evolution and Nubia-Somalia kinematics. Earth and Planetary Science Letters 301, 479-492. http://dx.doi.org/10.1016/j.epsl.2010.11.024.

Agostini, A., Bonini, M., Corti, G., Sani, F., Manetti, P., 2011b. Distribution of Quaternary deformation in the central Main Ethiopian Rift, East Africa. Tectonics 30, TC4010. http://dx.doi.org/10.1029/2010TC002833.

André-Mayer, A.-S., Sausse, J., 2007. Thickness and spatial distribution of veins in a porphyry copper deposit, Rosia Poieni, Romania. Journal of Structural Geology 29, 1695-1708. http://dx.doi.org/10.1016/j.jsg.2007.06.010.

Bastow, I., Keir, D., Daly, E., 2011. The Ethiopia Afar Geoscientific Lithospheric Experiment (EAGLE): probing the transition from continental rifting to incipient seafloor spreading. In: Beccaluva, L., Bianchini, G., Wilson, M. (Eds.), Volcanism and Evolution of the African Lithosphere: Spec. Pap. Geol. Soc. Am., 478, pp. 1-26. http:// dx.doi.org/10.1130/2011.2478(04).

Behn, M.D., Buck, W.R., Sacks, I.S., 2006. Topographic controls on dike injection in volcanic rift zones. Earth and Planetary Science Letters 246, 188-196. http://dx.doi.org/ 10.1016/j.epsl.2006.04.005.

Bialas, R.W., Buck, W.R., Qin, R., 2010. How much magma is required to rift a continent? Earth and Planetary Science Letters 292, 68-78. http://dx.doi.org/10.1016/j.epsl.2010.01.021.

Biggs, J., Bastow, I.D., Keir, D., Lewi, E., 2011. Pulses of deformation reveal frequently recurring shallow magmatic activity beneath the Main Ethiopian Rift. Geochemistry, Geophysics, Geosystems 12, Q0AB10. http://dx.doi.org/10.1029/2011GC003662.

Bilham, R., Bendick, R., Larson, K., Mohr, P., Braun, J., Tesfaye, S., Asfaw, L., 1999. Secular and tidal strain across the Main Ethiopian Rift. Geophysical Research Letters 26, 2789-2792.

Boccaletti, M., Bonini, M., Mazzuoli, R., Abebe, B., Piccardi, L., Tortorici, L., 1998. Quaternary oblique extensional tectonics in the Ethiopian Rift (Horn of Africa). Tectonophysics 287, 97-116.

Bonini, M., Mazzarini, F., 2010. Mud volcanoes as potential indicators of regional stress and pressurized layer depth. Tectonophysics 494, 32-47. http://dx.doi.org/10.1016/ j.tecto. 2010.08.006

Bonini, M., Corti, G., Innocenti, F., Manetti, P., Mazzarini, F., Abebe, T., Pècksay, Z., 2005. The evolution of the Main Ethiopian Rift in the frame of Afar and Kenya rifts propagation. Tectonics 24, TC1007. http://dx.doi.org/10.1029/2004TC001680.

Bonnet, E., Bour, O., Odling, N.E., Davy, P., Main, I., Cowie, P., Berkowitz, B., 2001. Scaling of fracture systems in geological media. Reviews of Geophysics 39, 347-383. http://dx.doi.org/10.1029/1999RG000074.

Bour, O., Davy, P., 1999. Clustering and size distribution of fault patterns: theory and measurements. Geophysical Research Letters 26, 2001-2004. http://dx.doi.org/ 10.1029/1999 GL900419.

Bour, O., Davy, P., Darcel, C., Odling, N., 2002. A statistical scaling model for fracture network geometry, with validation on a multiscale mapping of a joint network (Hornelen Basin, Norway). Journal of Geophysical Research 107, 2113. http:// dx.doi.org/10.1029/2001JB000176.

Braile, L.W., Keller, G.R., Wendlandt, R.F., Morgan, P., Khan, M.A., 1995. The East African rift system. In: Olsen, K.H. (Ed.), Continental Rifts: Evolution, Structure, Tectonics. Development in Geotectonics, v. 25. Elsevier, Amsterdam, pp. 213-231.

Chernet, T., Hart, W.K., Aronson, J.L., Walter, R.C., 1998. New age constraints on the timing of volcanism and tectonism in the northern Main Ethiopian Rift southern Afar transition zone (Ethiopia). Journal of Volcanology and Geothermal Research 80, 267-280. http://dx.doi.org/10.1016/S0377-0273(97)00035-8.

Chorowicz, J., 2005. The East African Rift System. Journal of African Earth Sciences 43, 379-410. http://dx.doi.org/10.1016/j.jafrearsci.2005.07.019.

Clauset, A., Shalizi, C.R., Newman, M.E.J., 2009. Power-law distributions in empirical data. SIAM Review 51. http://dx.doi.org/10.1137/070710111 (661e703). 
Connor, C.B., Conway, F.M., 2000. Basaltic volcanic Fields. In: Sigurdsson, H. (Ed.), Encyclopedia of Volcanoes. Academic Press, New York, pp. 331-343.

Connor, C.B., Hill, B.E., 1995. Three nonhomogeneous Poisson models for the probability of basaltic volcanism: application to the Yucca Mountains region, Nevada. Journal of Geophysical Research 100, 10107-10125.

Cornwell, D.G., Mackenzie, G.D., Maguire, P.K.H., England, R.W., Asfaw, L.M., Oluma, B., 2006. Northern Main Ethiopian Rift crustal structure from new high-precision gravity data. In: Yirgu, G., Ebinger, C.J., Maguire, P.K.H. (Eds.), The Afar Volcanic Province Within the East African Rift System: Geol. Soc. Spec. Publ., 258, pp. 307-321.

Corti, G., 2009. Continental rift evolution: from rift initiation to incipient break-up in the Main Ethiopian Rift, East Africa. Earth-Science Reviews 96, 1-53. http:// dx.doi.org/10.1016/j.earscirev.2009.06.005.

Corti, G., Bonini, M., Conticelli, S., Innocenti, F., Manetti, P., Sokoutis, D., 2003. Analogue modelling of continental extension: a review focused on the relations between the patterns of deformation and the presence of magma. Earth-Science Reviews 63, 169-247. http://dx.doi.org/10.1016/S0012-8252(03)00035-7.

Corti, G., Philippon, M., Sani, F., Keir, D., Kidane, T., 2013. Re-orientation of the extension direction and pure extensional faulting at oblique rift margins: comparison between the Main Ethiopian Rift and laboratory experiments. Terra Nova. http:// dx.doi.org/10.1111/ter.12049.

Dahm, T., 2000. Numerical simulations of the propagation path and the arrest of fluidfilled fractures in the Earth. Geophysical Journal International 141, 623-638. http://dx.doi.org/10.1046/j.1365-246x.2000.00102.x.

Daly, E., Keir, D., Ebinger, C.J., Stuart, G.W., Bastow, I.D., Ayele, A., 2008. Crustal tomographic imaging of a transitional continental rift: the Ethiopian rift. Geophysical Journal International 172, 1033-1048. http://dx.doi.org/10.1111/ j.1365-246X.2007.03682.x.

Darcel, C., Bour, O., Davy, P., de Dreuzy, J.R., 2003a. Connectivity properties of twodimensional fracture networks with stochastic fractal correlation. Water Resources Research 39, 1272. http://dx.doi.org/10.1029/2002WR001628.

Darcel, C., Bour, O., Davy, P., 2003b. Stereological analysis of fractal fracture networks. Journal of Geophysical Research 108 (B9), 2451. http://dx.doi.org/10.1029/ 2002JB002091.

Ebinger, C.J., Casey, M., 2001. Continental breakup in magmatic provinces: an Ethiopian example. Geology 29, 527-530. http://dx.doi.org/10.1130/0091-7613(2001)029<0527: CBIMPA $>2.0 . \mathrm{CO} ; 2$

Favalli, M., Tarquini, S., Papale, P., Fornaciai, A., Boschi, E., 2012. Lava flow hazard and risk at Mt. Cameroon volcano. Bulletin of Volcanology 74, 423-439. http://dx.doi.org/ 10.1007/s00445-011-0540-6.

Gillespie, P.A., Johnston, J.D., Loriga, M.A., McCaffrey, K.J.W., Walsh, J.J., Watterson, J., 1999. Influence of layering on vein systematics in line samples. In: McCaffrey, K.J.W., Lonergan, L., Wilkinson, J.J. (Eds.), Fractures, Fluid Flow and Mineralization: Geological Society London, Special Publication, 155, pp. 35-56.

Gross, M.R., 1993. The origin and spacing of cross joints: examples from the Monterey Formation, Santa Barbara coastline, California. Journal of Structural Geology 15 , 737-751. http://dx.doi.org/10.1016/0191-8141(93)90059-J.

Gudmundsson, A., 2002. Emplacement and arrest of sheets and dykes in central volcanoes. Journal of Geophysical Research 116, 279-298.

Hayward, N.J., Ebinger, C.J., 1996. Variations in the along-axis segmentation of the Afar Rift system. Tectonics 15, 244-257. http://dx.doi.org/10.1029/95TC02292.

Hentschel, H.G.E., Procaccia, I., 1983. The infinite number of generalised dimension of fractals and strange attractors. Physica 8D, 435-444

Keir, D., Ebinger, C.J., Stuart, G.W., Daly, E., Ayele, A., 2006. Strain accommodation by magmatism and faulting as rifting proceeds to breakup: seismicity of the northern Ethiopian rift. Journal of Geophysical Research 111, B05314. http://dx.doi.org/ 10.1029/2005JB003748.

Keir, D., Bastow, I.D., Whaler, K.A., Daly, E., Cornwell, D.G., Hautot, S., 2009. Lower crustal earthquakes near the Ethiopian rift induced by magmatic processes. Geochemistry, Geophysics, Geosystems 10. http://dx.doi.org/10.1029/2009GC002382 (O0AB = 2)

Keir, D., Belachew, M., Ebinger, C.J., Kendall, J.-M., Hammond, J.O.S., Stuart, G.W., Ayele, A., Rowland, J.V., 2011a. Mapping the evolving strain field during continental breakup from crustal anisotropy in the Afar Depression. Nature Communications 2, 285. http://dx.doi.org/10.1038/ncomms1287.

Keir, D., Pagli, C., Bastow, I.D., Ayele, A., 2011b. The magma-assisted removal of Arabia in Afar: evidence from dike injection in the Ethiopian rift captured using InSAR and seismicity. Tectonics 30, TC2008. http://dx.doi.org/10.1029/2010TC002785.

Keranen, K., Klemperer, S.L., 2008. Discontinuous and diachronous evolution of the Main Ethiopian Rift: implications for development of continental rifts. Earth and Planetary Science Letters 265, 96-111. http://dx.doi.org/10.1016/j.epsl.2007.09.038.

Keranen, K., Klemperer, S.L., Gloaguen, R., Eagle working group, 2004. Three-dimensional seismic imaging of a protoridge axis in the Main Ethiopian rift. Geology 32, 949-952.

Keranen, K., Klemperer, S.L., Julia, J., Lawrence, J.L., Nyblade, A., 2009. Low lower-crustal velocity across Ethiopia: is the Main Ethiopian Rift a narrow rift in a hot craton? Geochemistry, Geophysics, Geosystems 10, Q0AB01. http://dx.doi.org/10.1029/ 2008GC002293.

Kieffer, B., Arndt, N., Lapierre, H., Bastien, F., Bosch, D., Pecher, A., Yirgu, G., Ayalew, D. Weis, D., Jerram, D.A., Keller, F., Meugniot, C., 2004. Flood and shield basalts from Ethiopia: magmas from the African superswell. Journal of Petrology 45, 793-834. http://dx.doi.org/10.1093/petrology/egg112.

Kiyosugi, K., Connor, C.B., Wetmore, P.H., Ferwerda, B.P., Germa, A.M., Connor, L.J. Hintz, A.R., 2012. Relationship between dike and volcanic conduit distribution in a highly eroded monogenetic volcanic field: San Rafael, Utah, USA. Geology 40, 695-698. http://dx.doi.org/10.1130/G33074.1

Kogan, L., Fiesseha, S., Bendick, R., eilinger, R., McClusky, S., King, R., Solomon, T., 2012. Lithospheric strength and strain localisation in continental extension from observations of the East African Rift. Journal of Geophysical Research 117. http://dx.doi.org/10.1029/ 2011JB008516.

Lahitte, P., Gillot, P.-Y., Kidane, T., Courtillot, V., Abebe, B., 2003a. New age constraints on the timing of volcanism in central Afar, in the presence of propagating rifts. Journal of Geophysical Research 108, 2123. http://dx.doi.org/10.1029/ 2001JB001689.

Lahitte, P., Gillot, P.-Y., Courtillot, V., 2003b. Silicic central volcanoes as precursors to rift propagation: the Afar case. Earth and Planetary Science Letters 207, 103-116. http://dx.doi.org/10.1016/S0012-821X(02)01130-5.

Lister, J.R., Kerr, R.C., 1991. Fluid-mechanical models of crack propagation and their application to magma transport in dykes. Journal of Geophysical Research 96, 10,049-10,077. http://dx.doi.org/10.1029/91JB00600.

Mackenzie, G.D., Thybo, H., Maguire, P.K.H., 2005. Crustal velocity structure across the Main Ethiopian Rift: results from two-dimensional wide-angle seismic modelling Geophysical Journal International 162, 994-1006. http://dx.doi.org/10.1111/j.1365246X.2005.02710.x.

Maguire, P.K.H., Keller, G.R., Klemperer, S.L., Mackenzie, G.D., Keranen, K., Harder, S. O'Railly, B., Thybo, H., Asfaw, L., Khan, M.A., Amhua, M., 2006. Crustal structure of the northern Main Ethiopian Rift from the EAGLE controlled-source survey; a snapshot of incipient lithospheric break-up. In: Yirgu, G., Ebinger, C.J., Maguire, P.K.H (Eds.), The Afar Volcanic Province Within the East African Rift System: Geological Society, London, Special Publication, 259, pp. 269-292.

Mahatsente, R., Jentzsch, G., Jahr, T., 1999. Crustal structure of the Main Ethiopian rift gravity data: 3-dimensional modeling. Tectonophysics 313, 363-382. http:// dx.doi.org/10.1016/S0040-1951(99)00213-9.

Mazzarini, F., 2004. Volcanic vent self-similar clustering and crustal thickness in the northern Main Ethiopian Rift. Geophysical Research Letters 31, L04604. http:// dx.doi.org/10.1029/2003GL018574.

Mazzarini, F., 2007. Vent distribution and crustal thickness in stretched continenta crust: the case of the Afar Depression (Ethiopia). Geosphere 3, 152-162. http:/ dx.doi.org/10.1130/GES00070.1.

Mazzarini, F., D'Orazio, M., 2003. Spatial distribution of cones and satellite-detected lineaments in the Pali Aike Volcanic Field (southernmost Patagonia): insights into the tectonic setting of a Neogene rift system. Journal of Volcanology and Geothermal Research 125, 291-305. http://dx.doi.org/10.1016/S0377-0273(03) 00120-3.

Mazzarini, F., Isola, I., 2010. Monogenetic vent self-similar clustering in extending continental crust: examples from the East African Rift System. Geosphere 6, 567-582. http://dx.doi.org/10.1130/GES00569.1.

Mazzarini, F., Abebe, T., Innocenti, F., Manetti, P., Pareschi, M.T., 1999. Geology of the Debre Zeyt area (Ethiopia) (with a geological map at scale 1:100,000), Acta Vulcanol. 11, 131-141.

Mazzarini, F., Corti, G., Manetti, P., Innocenti, F., 2004. Strain rate and bimodal volcanism in the continental rift: Debre Zeyt volcanic field, northern MER. Ethiopia Journal of African Earth Sciences 39, 415-420. http://dx.doi.org/10.1016/j.jafrearsci.2004.07.025.

Mazzarini, F., Fornaciai, A., Bistacchi, A., Pasquarè, F.A., 2008. Fissural volcanism, polygenetic volcanic fields, and crustal thickness in the Payen Volcanic Complex on the central Andes foreland (Mendoza, Argentina). Geochemistry, Geophysics, Geosystems 9, Q09002. http://dx.doi.org/10.1029/2008GC002037.

Mazzarini, F., Ferrari, L., Isola, I., 2010. Self-similar clustering of cinder cones and crus thickness in the Michoacan-Guanajuato and Sierra de Chichinautzin volcanic fields, Trans-Mexican Volcanic Belt. Tectonophysics 486, 55-64. http://dx.doi.org/ 10.1016/j.tecto.2010.02.009.

Mazzarini, F., Rooney, T., Isola, I., 2013. The intimate relationship between strain and magmatism: a numerical treatment of clustered monogenetic fields in the Main Ethiopian Rift. Tectonics 32, 49-64. http://dx.doi.org/10.1029/2012TC003146.

McKenzie, D., 1978. Some remarks on development of sedimentary basins. Earth and Planetary Science Letters 40, 25-32. http://dx.doi.org/10.1016/0012-821X(78) 90071-7.

Mickus, K., Tadesse, K., Keller, G.R., Oluma, B., 2007. Gravity analysis of the main Ethiopian rift. Journal of African Earth Sciences 48, 59-69. http://dx.doi.org/10.1016 j.jafrearsci.2007.02.008.

Mohr, P.A., 1967. Major volcano-tectonic lineament in the Ethiopian rift system. Nature $213,664-665$

Morton, W.H., Rex, D.C., Mitchell, J.G., Mohr, P.A., 1979. Rift ward younging of volcanic units in the Addis Ababa region, Ethiopian rift valley. Nature 280, 284-288. http:// dx.doi.org/10.1038/280284a0.

Narr, W., Suppe, J., 1991. Joint spacing in sedimentary rocks. Journal of Structural Geology 13, 1037-1048. http://dx.doi.org/10.1016/0191-8141(91)90055-N

Peccerillo, A., Barberio, M.R., Yirgu, G., Ayalew, D., Barbieri, M., Wu, T.W., 2003. Relationships between mafic and peralkaline silicic magmatism in continental rift settings: a petrological, geochemical and isotopic study of the Gedemsa volcano, central Ethiopian rift. Journal of Petrology 44, 2003-2032.

Petford, N., Cruden, A.R., McCaffrey, K.J.W., Vigneresse, J.L., 2000. Granite magma formation, transport and emplacement in the Earth's crust. Nature 408, 669-673. http://dx.doi.org/10.1038/35047000.

Renshaw, C.E., 1997. Mechanical controls on the spatial density of opening-mode fracture networks. Geology 25, 923-926. http://dx.doi.org/10.1130/0091-7613(1997) 025<0923:MCOTSD>2.3.CO;2.

Rooney, T.O., 2010. Geochemical evidence of lithospheric thinning in the southern Main Ethiopian Rift. Lithos 117, 33-48. http://dx.doi.org/10.1016/j.lithos.2010.02.002.

Rooney, T., Furman, T., Yirgu, G., Ayelew, D., 2005. Structure of the Ethiopian lithosphere: evidence from mantle xenoliths. Geochemica et Cosmochimica Acta 69, 3889-3910.

Rooney, T., Furman, T., Bastow, I., Ayalew, D., Yirgu, G., 2007. Lithospheric modification during crustal extension in the Main Ethiopian Rift. Journal of Geophysical Research 112, B10201. http://dx.doi.org/10.1029/2006JB004916. 
Rooney, T.O., Bastow, I.D., Keir, D., 2011. Insights into extensional processes during magma assisted rifting: evidence from aligned scoria cones and maars. Journal of Volcanology and Geothermal Research 201, 83-96. http://dx.doi.org/10.1016/ j.jvolgeores.2010.07.019.

Rosendahl, B.L., 1987. Architecture of continental rifts with special reference to east Africa. Annual Review of Earth and Planetary Sciences 15, 445-503. http://dx.doi.org/ 10.1146/annurev.ea.15.050187.002305.

Rubin, A.M., 1995. Propagation of magma-filled crack. Annual Review of Earth and Planetary Sciences 23, 287-336. http://dx.doi.org/10.1146/annurev.ea.23.050195.001443.

Rubin, A.M., Pollard, D.D., 1988. Dike-induced faulting in rift zones of Iceland and Afar Geology 16, 413-417. http://dx.doi.org/10.1130/0091-7613(1988)016<0413: DIFIRZ $>2.3 . C O ; 2$.

Shillington, D.J., Scott, C.L., Minshull, T.A., Edwards, R.A., Brown, P.J., White, N.J., 2009 Abrupt transition from magma-starved to magma rich rifting in the eastern Black Sea. Geology 37, 7-10. http://dx.doi.org/10.1130/G25302A.1.

Stuart, G.W., Bastow, I.D., Ebinger, C.J., 2006. Crustal structure of the northern Main Ethiopian Rift from receiver function study. In: Yirgu, G., Ebinger, C.J., Maguire, P.K.H. (Eds.), The Afar Volcanic Province Within the East African Rift System: Geological Society, London, Special Publication, 259, pp. 253-267.

Tibaldi, A., 1995. Morphology of pyroclastic cones and tectonics. Journal of Geophysical Research 100, 24,521-24,535. http://dx.doi.org/10.1029/95JB02250.
Tiberi, C., Ebinger, C., Ballu, V., Stuart, G., Oluma, B., 2005. Inverse models of gravity data from the Red Sea-Aden-East African rifts triple junction zone. Geophysical Journal International 163, 775-787. http://dx.doi.org/10.1111/j.1365-246X.2005.02736.x.

Trua, T., Deniel, C., Mazzuoli, R., 1999. Crustal control in the genesis of Plio-Quaternary bimodal magmatism of the Main Ethiopian Rift (MER): geochemical and isotopic ( $\mathrm{Sr}$, $\mathrm{Nd}$ and $\mathrm{Pb}$ ) evidence. Chemical Geology 155, 201-231. http://dx.doi.org/10.1016/ S0009-2541(98)00174-0.

Walsh, J. Watterson, J. 1993. Fractal analysis of fracture pattern using the standard box-counting technique: valid and invalid methodologies. Journal of Structural Geology 15, 1509-1512. http://dx.doi.org/10.1016/0191-8141(93) 90010-8.

Whaler, K.A., Hautot, S., 2006. The electrical resistivity structure of the crust beneath the northern Main Ethiopian Rift. In: Yirgu, G., Ebinger, C.J., Maguire, P.K.H. (Eds.), The Afar Volcanic Province within the East African Rift System: Geological Society London, Special Publication, 259, pp. 293-305.

WoldeGabriel, G., Aronson, J.L., Walter, R.C., 1990. Geology, geochronology, and rift basin development in the central sector of the Main Ethiopia Rift. Geological Society of America Bulletin 102, 439-458.

Wolfenden, E., Ebinger, C., Yirgu, G., Deino, A., Ayale, D., 2004. Evolution of the northern Main Ethiopian rift: birth of a triple junction. Earth and Planetary Science Letters 224, 213-228. http://dx.doi.org/10.1016/j.epsl.2004.04.022. 